\title{
Evaluation and bias correction of satellite rainfall data for drought monitoring in Indonesia
}

\author{
R. R. E. Vernimmen ${ }^{1}$, A. Hooijer ${ }^{1}$, Mamenun ${ }^{2}$, E. Aldrian ${ }^{2}$, and A. I. J. M. van Dijk ${ }^{3}$ \\ ${ }^{1}$ Deltares, P.O. Box 177, 2600 MH, Delft, The Netherlands \\ ${ }^{2}$ Meteorological Climatological and Geophysical Agency of Indonesia (BMKG), Jl.Angkasa I No. 2, \\ Jakarta 10720, P.O. Box 3540 JKT, Indonesia \\ ${ }^{3}$ CSIRO Land and Water, GPO 1666, 2601 Canberra, ACT, Australia
}

Correspondence to: R. R. E. Vernimmen (ronald.vernimmen@deltares.nl)

Received: 9 March 2011 - Published in Hydrol. Earth Syst. Sci. Discuss.: 22 June 2011

Revised: 5 December 2011 - Accepted: 3 January 2012 - Published: 12 January 2012

\begin{abstract}
The accuracy of three satellite rainfall products (TMPA 3B42RT, CMORPH and PERSIANN) was investigated through comparison with grid cell average ground station rainfall data in Indonesia, with a focus on their ability to detect patterns of low rainfall that may lead to drought conditions. Each of the three products underestimated rainfall in dry season months. The CMORPH and PERSIANN data differed most from ground station data and were also very different from the TMPA 3B42RT data. It proved possible to improve TMPA 3B42RT estimates by applying a single empirical bias correction equation that was uniform in space and time. For the six regions investigated, this reduced the root mean square error for estimates of dry season rainfall totals by a mean $9 \%$ (from 44 to $40 \mathrm{~mm}$ ) and for annual totals by $14 \%$ (from 77 to $66 \mathrm{~mm}$ ). The resulting errors represent $10 \%$ and $3 \%$ of mean dry season and annual rainfall, respectively. The accuracy of these bias corrected TMPA 3B42RT data is considered adequate for use in realtime drought monitoring in Indonesia. Compared to drought monitoring with only ground stations, this use of satellitebased rainfall estimates offers important advantages in terms of accuracy, spatial coverage, timeliness and cost efficiency.
\end{abstract}

\section{Introduction}

Indonesia is a tropical maritime country and most of it receives abundant annual rainfall; e.g. in excess of $2300 \mathrm{~mm}$ per year across Java (Aldrian and Djamil, 2008). In large parts of the country, however, rainfall is highly seasonal and in some areas and seasons erratic. This is the case particularly in areas furthest south of the Equator including the densely populated island of Java as well as the southern parts of Sumatra, Kalimantan and Papua (Aldrian and Susanto, 2003). In these regions, water deficits lasting several months can occur and cause failures of water supply systems and of rain fed and irrigated crops (Kirono and Tapper, 1999; Naylor et al., 2001), as well as contribute to enhanced fire risk in forests and peat land areas (Field et al., 2004). Monitoring and understanding dry season rainfall patterns, in time and space, can assist in better preparation for drought conditions. Outside a few densely populated areas, rainfall monitoring at ground stations over most of Indonesia does not at present provide data with the speed, reliability and accuracy required for early warning of droughts. Moreover, ground stations are too sparse to achieve the coverage needed for accurate analysis of rainfall patterns, especially as spatial variability in rainfall is high in this country, which has thousands of islands and high mountain ranges. It would therefore be useful if satellite-based sensors could yield rainfall information that is available with very limited delay, has adequate accuracy, 
and has full coverage over the country, including the more remote areas. Over the last decade, several remotely sensed rainfall estimate products have been developed that use data from several satellites, with different types of instruments. Remote sensing of precipitation relies on the relationship between rainfall rate and cloud top temperature as observed by infrared (IR) satellite instruments, or from the influence of rain drops and ice particles on microwave (MW) radiation, or both. In addition, the Tropical Rainfall Measuring Mission (TRMM) carries a precipitation radar instrument, similar to radar used on the ground for detecting rain (Huffman et al., 2007). Although radar and MW-derived estimates of instantaneous rainfall rates are the more accurate, the currently best performing remote sensing methods all combine MW and IR observations to deal with the temporally infrequent MW sampling (MW observations are from instruments on polar-orbiting satellites and therefore infrequent; high temporal frequency IR observations from geostationary satellites are needed to interpolate in time).

Several satellite precipitation products exist (see Sapiano and Arkin, 2009) but three combined MW-IR satellite precipitation products have for some time been available via the internet in near real-time, and are therefore of particular interest for operational early warning systems.

The time series of satellite rainfall data have only recently become long enough for confident analysis of their usefulness for water resources management (the earliest going back to 1998). National meteorological organizations are unlikely to adopt such data as a primary information source unless they are thoroughly evaluated for the specific conditions in their countries, based on a sufficiently long historical record covering the full range of climate conditions. A number of comparisons of satellite precipitation products against (up-scaled) station rainfall observations have been published, varying from detailed local and short-term comparisons (Curtis et al., 2007; Scheel et al., 2011; Villarini and Krajewski, 2007) to ongoing initiatives providing nearreal time evaluation statistics over large areas (Ebert et al., 2007). Most quantitative satellite rainfall evaluation studies focus on northern America, Europe and Australia, and few have evaluated the accuracy of satellite products in humid tropical environments outside these continents.

Within the hydrological community, studies using satellite rainfall have mostly focused on potential use in river flow forecasting (Behrangi et al., 2011; Su et al., 2008), often with an emphasis on the ability to accurately measure high rainfall rather than low rainfall. Most studies concluded that TRMM data are usefully accurate at monthly time steps, but less so at daily time steps (Su et al., 2008), which limits its use for flood forecasting. Current uses of satellite rainfall products in water resources monitoring systems early drought warning systems were reviewed by Van Dijk and Renzullo (2011). In general, operational systems currently use rainfall estimates produced by weather forecasting systems (which assimilate satellite observations) and/or gauge-based rainfall estimates. However, the potential value of satellite precipitation products for regions with poor on-ground networks is well recognised, and TRMM Multi-satellite Precipitation Analysis (TMPA) and PERSIANN (Precipitation Estimation from Remotely Sensed Information Using Neural Networks) rainfall estimates are used in the experimental African Drought Monitor (Sheffield et al., 2008).

We are not aware of any studies examining the suitability of satellite rainfall products for water resources or drought monitoring in seasonal tropical maritime environments such as found in Indonesia. In this setting, accurate knowledge of rainfall during dry periods is especially critical. The strong maritime influence and relief cause very high spatial variability in rainfall that challenges interpolation on the basis of on-ground gauges. This means that satellite products may potentially play a valuable role, but their accuracy too, may be influenced by topography and coastal influences. In this study, we investigate the accuracy of three satellite rainfall products for Indonesia. In addition, we developed a simple method to correct the products for bias in real-time to achieve a better agreement with rainfall measured at ground stations.

\section{Methods and results}

\subsection{Satellite rainfall products}

We studied the real-time products TMPA 3B42RT (Huffman et al., 2007), CMORPH (Joyce et al., 2004) and PERSIANN (Sorooshian et al., 2000). All are available at $0.25^{\circ} \times 0.25^{\circ}$ spatial resolution and 3-h temporal resolution.

Each of the three products evaluated here combines MW and IR data in somewhat different ways. The real-time TRMM Multi-satellite Precipitation Analysis 3B42 Real Time product (TMPA 3B42RT, Huffman et al., 2007) uses MW-derived precipitation estimates available from various satellites within the $3 \mathrm{~h}$ time step and $0.25^{\circ}$ grid cell, after which missing data are estimated using IR estimates calibrated against the MW-derived values; in addition, it is the only product to use the TRMM instrument radar observations. The Precipitation Estimation from Remotely Sensed Information Using Neural Networks product (PERSIANN, Sorooshian et al., 2000) is developed with artificial neural networks estimating rain rates from IR data, with adjustments in the network parameters based on MW-derived and on-ground rain rates where available (Hsu et al., 1997). The Climate Prediction Center Morphing product (CMORPH, Joyce et al., 2004) product uses IR-based cloud tracking to interpolate between successive precipitation fields derived from MW observations. 

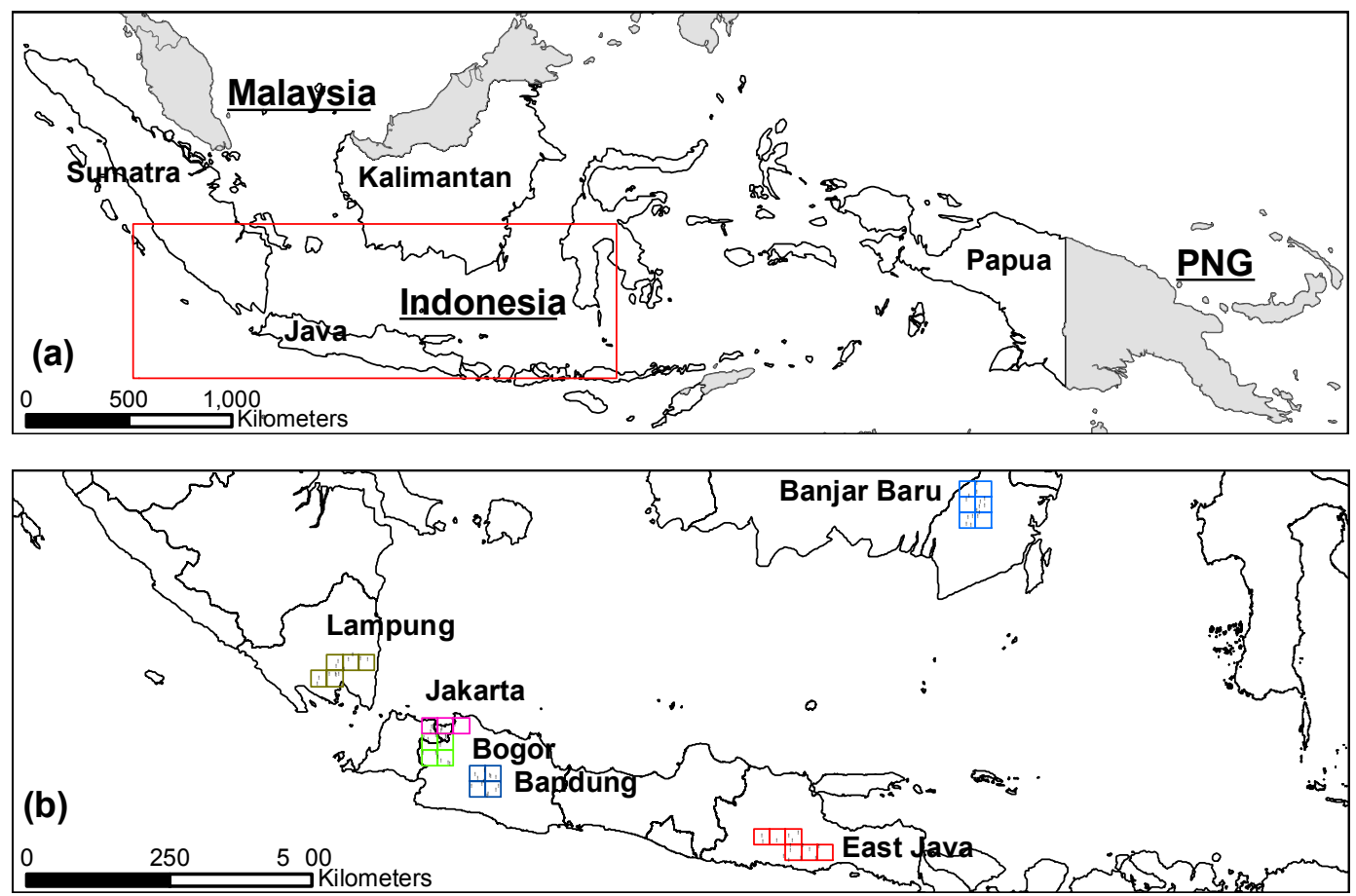

Fig. 1. (a) Map of Indonesia (and Malaysia, Brunei, Singapore, Papua New Guinea (PNG) and East Timor, grey areas). The red box is shown in more detail in (b). (b) TMPA 3B42RT validation areas indicated in different colours. Each square represents one satellite grid cell of $0.25^{\circ} \times 0.25^{\circ}$. The black dots are the locations of the ground stations.

Table 1. Descriptive characteristics of the validation areas. Ground station data coverage for the period 2003-2008. Elevation determined from SRTM $90 \mathrm{~m}$ resolution (Jarvis et al., 2008). Forest and urban cover determined from GlobCover v2.2 regional land cover map over Southeast Asia (ESA, 2008).

\begin{tabular}{|c|c|c|c|c|c|c|c|c|}
\hline $\begin{array}{l}\text { Validation } \\
\text { region }\end{array}$ & $\begin{array}{r}\text { No. of } \\
\text { grid } \\
\text { cells }\end{array}$ & $\begin{array}{l}\text { No. of } \\
\text { ground } \\
\text { stations }\end{array}$ & $\begin{array}{r}\text { Ground } \\
\text { station } \\
\text { coverage }\end{array}$ & $\begin{array}{r}\text { Avg. } \\
\text { ground } \\
\text { station } \\
\text { elev. }\end{array}$ & $\begin{array}{l}\text { Avg. } \\
\text { area } \\
\text { elev. }\end{array}$ & $\begin{array}{r}\text { Distance } \\
\text { from } \\
\text { coast }\end{array}$ & $\begin{array}{l}\text { Forest } \\
\text { cover* }\end{array}$ & $\begin{array}{l}\text { Urban } \\
\text { cover }\end{array}$ \\
\hline & & & $\%$ time & $\mathrm{m}$ & $\mathrm{m}$ & $\mathrm{km}$ & $\%$ & $\%$ \\
\hline Jakarta & 3 & 10 & 89 & 13 & 8 & $0-30$ & 2.1 & 31.8 \\
\hline Bogor & 4 & 10 & 99 & 354 & 331 & $30-90$ & 25.7 & 10.6 \\
\hline Bandung & 4 & 13 & 96 & 978 & 1050 & $30-90$ & 40.1 & 9.1 \\
\hline East Java & 6 & 15 & 91 & 492 & 619 & $0-60$ & 29 & 0.5 \\
\hline Banjar Baru & 6 & 15 & 83 & 19 & 52 & $90-180$ & 51.2 & 0 \\
\hline Lampung & 5 & 13 & 90 & 83 & 120 & $0-60$ & 15.3 & 0.4 \\
\hline
\end{tabular}

* Including degraded forest and plantation forest.

Rainfall estimates derived from the TRMM satellite have been collected since 1998 and are available as a real time product since early 2002, whereas CMORPH and PERSIANN data are available since 2003 and 2000, respectively. The algorithm of the TMPA 3B42RT product used in this study is Version 5. A newer "Version 6" algorithm of TMPA 3B42RT was issued in 2009, with the record beginning in late 2008. The new version also includes an "uncalibrated" field that provides continuity with the previous version.

\subsection{Selection and screening of ground station rainfall data}

As validation areas, grid cells were selected that had a sufficiently large number of stations observations during the period 2003-2008 (Fig. 1). Having a relatively high station density was necessary to (i) allow station data quality control by cross-comparison, and (ii) to ensure that several stations are present in each of the TMPA grid cells covering the area, 


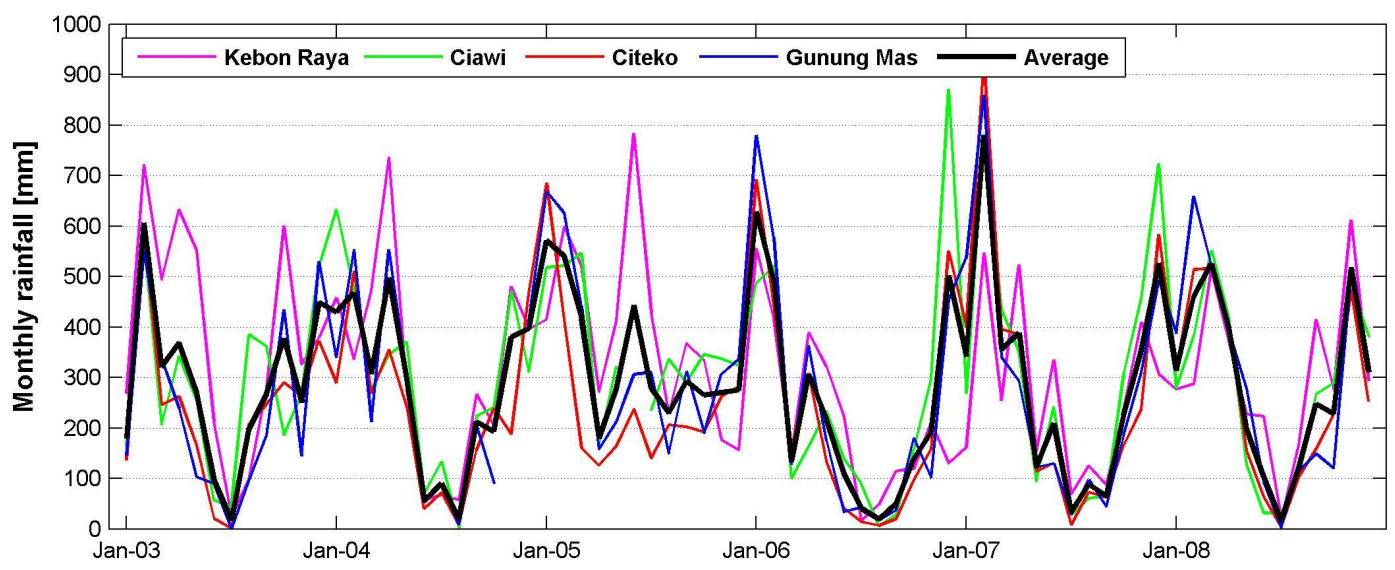

Fig. 2. Monthly ground station rainfall records for the period 2003-2008 in a single satellite grid cell, around Bogor.

to provide a larger scale average rainfall estimate. This led to six clusters of rainfall stations around Jakarta, Bogor, Bandung and East Java (Java), and Banjar Baru (Kalimantan) and Lampung (Sumatra) (Table 1).

Within the validation areas, monthly station rainfall records (derived from daily measurements) were selected that had data coverage for over $75 \%$ of the time during the study period. The data were checked for consistency by carrying out double mass curve analysis. As a result of this analysis, unreasonable values such as zero-rainfall months during the wet season were deleted. Data that appeared gapfilled using data from other stations or years were also excluded. After screening, a total of 76 stations were found suitable, having 10 to 15 stations for each of the six areas. Temporal data coverage was $>67 \%$ for individual stations and $83-99 \%$ for each of the six groups of stations (Table 1).

It was considered important to have more than one ground station in each satellite grid cell in the comparison because the gridded satellite data represent a measure of average rainfall over the grid cells; an area of $772 \mathrm{~km}^{2}\left(0.25^{\circ}\right.$ equals to approximately $27.78 \mathrm{~km}$ near the equator). Tropical rainstorms tend to be localized, with heavy rainfall sometimes affecting an area of less than $10 \mathrm{~km}$ across. This will result in differences in rainfall rates over short distances within satellite grid cells. Moreover, in a mountainous island country like Indonesia many grid cells cover a considerable altitude range, which can cause non-random patterns in rainfall rate. An example of the differences between rainfall records from four reliable ground stations within a single satellite grid cell in the rather mountainous Bogor area is shown in Fig. 2. Combining data for more than one ground station will therefore likely be more representative of average rainfall in an area the size of a satellite grid cell.

Grid cell average monthly ground station time series plots for each of the six validation areas are shown in Fig. 3. Different rainfall regimes are apparent for different areas, but the seasonality is largely the same, with June-October usually being the driest months. Validating and bias correcting satellite data for these six areas, each different in terms of distance to the coast, elevation, land cover (Table 1) and rainfall rates (Table 2), builds confidence that the resulting error estimates and bias corrections will be appropriate for the range of conditions found in Indonesia.

\subsection{Comparing satellite with ground station rainfall data}

To assess the accuracy of the remote sensing products, comparisons were performed with grid cell average rainfall based on ground measurements. All three satellite products have been available in near real-time since 2003, and ground station data after 2008 are incomplete, therefore the selected study period was 2003 to 2008 (6 full years). Over this period, the daily estimates from satellite were aggregated to monthly totals, for all grid cells that cover Indonesia's land area (as well as the neighbouring countries of Malaysia, Singapore and Brunei, which are in the same rectangular region; Fig. 1a). The monthly satellite data for the grid cells covering the validation areas were then averaged, weighted for the number of stations in each TMPA grid cell (Fig. 1b). Figure 4 shows the double mass curves for each of the individual validation areas, one for each satellite product investigated. It is evident that most products have a considerable bias, although this bias is not always consistent between the individual validation areas. Overall, PERSIANN has the highest positive bias (overestimate) whereas CMORPH has the highest negative bias (underestimate). The TMPA 3B42RT bias is smallest in most cases, being either somewhat positive or somewhat negative in different areas. In each of the double mass curves a breaking point in the TMPA 3B42RT line is seen at approximately 4000-5000 mm which coincides with early 2005 . This may be explained by the incorporation of additional rainfall intensity estimates, from the AMSU-B and AMSR-E satellite instruments from February 2005 onwards (Huffman and Bolvin, 2010). Although 


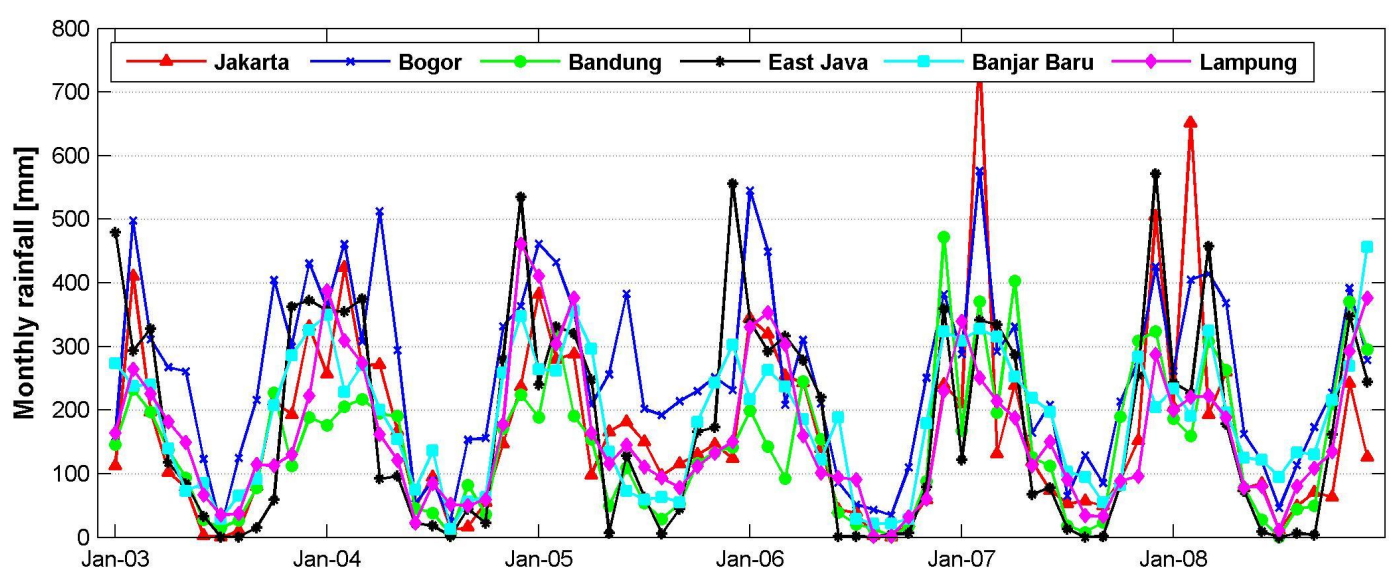

Fig. 3. Average monthly ground station rainfall for the six validation areas for the period 2003-2008.

Table 2. Average annual precipitation $(P$, in $\mathrm{mm})$ and relative bias $(\%)$ over the period $2003-2008$ for ground stations, and satellite products TMPA 3B42RT, CMORPH and PERSIANN.

\begin{tabular}{|c|c|c|c|c|c|c|c|}
\hline \multirow[t]{2}{*}{$\begin{array}{l}\text { Validation } \\
\text { region }\end{array}$} & \multirow{2}{*}{$\begin{array}{r}\text { Ground } \\
\text { stations } \\
P\end{array}$} & \multicolumn{2}{|c|}{ TMPA } & \multicolumn{2}{|c|}{ CMORPH } & \multicolumn{2}{|c|}{ PERSIANN } \\
\hline & & $P$ & rel. bias & $P$ & rel. bias & $P$ & rel. bias \\
\hline Jakarta & 2010 & 1865 & -7.2 & 1155 & -42.6 & 2524 & 25.5 \\
\hline Bogor & 3056 & 2944 & -3.7 & 2246 & -26.5 & 3087 & 1.0 \\
\hline Bandung & 1723 & 1936 & 12.3 & 1690 & -1.9 & 2806 & 62.9 \\
\hline East Java & 2106 & 1835 & -12.8 & 1417 & -32.7 & 2077 & -1.4 \\
\hline Banjar Baru & 2208 & 2217 & 0.4 & 2264 & 2.6 & 2783 & 26.1 \\
\hline Lampung & 1946 & 2191 & 12.6 & 1695 & -12.9 & 3182 & 63.5 \\
\hline
\end{tabular}

the validation period is too short to confidently quantify this change, it appears that TMPA 3B42RT data have become more accurate since 2005 .

The annual and dry season relative bias (Eq. 1) for each of the products as well as rainfall total is shown in Tables 2 and 3. While different definitions of "dry season" exist in Indonesia (Wyrtki, 1956; Aldrian and Susanto, 2003), for different regions and purposes, we have defined it here as JuneOctober, the period over which the validation areas had average rainfall below that in the remainder of the year, in most cases below $100 \mathrm{~mm}$ per month (except in Bogor where it is $143 \mathrm{~mm}$ per month), which defines "dry" conditions sensu Brünig (1969) and Oldeman et al. (1979, 1980).

Relative bias (bias) $=\frac{\sum_{i=1}^{N} P_{\text {groundst. }(i)}-P_{\text {satellite }(i)}}{\sum_{i=1}^{N} P_{\text {groundst. }(i)}} \times 100$

where $N$ is the number of months.

Relative bias on an annual basis varies between -12.8 to $12.6 \%$ for TMPA 3B42RT, -42.6 to $2.6 \%$ for CMORPH and -1.4 to $63.5 \%$ for PERSIANN (Table 2). Dry season relative bias is greater compared to the annual relative bias, ranging from -55.1 to $1.0 \%$ for TMPA 3B42RT, -55.6 to $8.7 \%$ for CMORPH and -63.7 to $9.5 \%$ for PERSIANN (Table 3).

\subsection{Spatial comparison of average annual rainfall from satellite products for Indonesia}

Maps of annual rainfall were generated using the three different satellite rainfall products. The relative differences between these maps are shown in (Fig. 5). Consistent difference patterns are evident when comparing TMPA 3B42RT and CMORPH. Compared to TMPA 3B42RT, estimates of CMORPH are up to $50 \%$ lower along the coast (decreasing with distance from the coast), whereas further inland CMORPH is up to $50 \%$ higher (especially in the mountainous area of Papua, Fig. 5a). Major differences are also evident when comparing TMPA 3B42RT and PERSIANN (Fig. 5b). However, in this case no consistent patterns are evident. It appears that PERSIANN has much higher rainfall amounts in Sumatra when compared with TMPA 3B42RT, whereas difference patterns elsewhere appear to be almost random. 

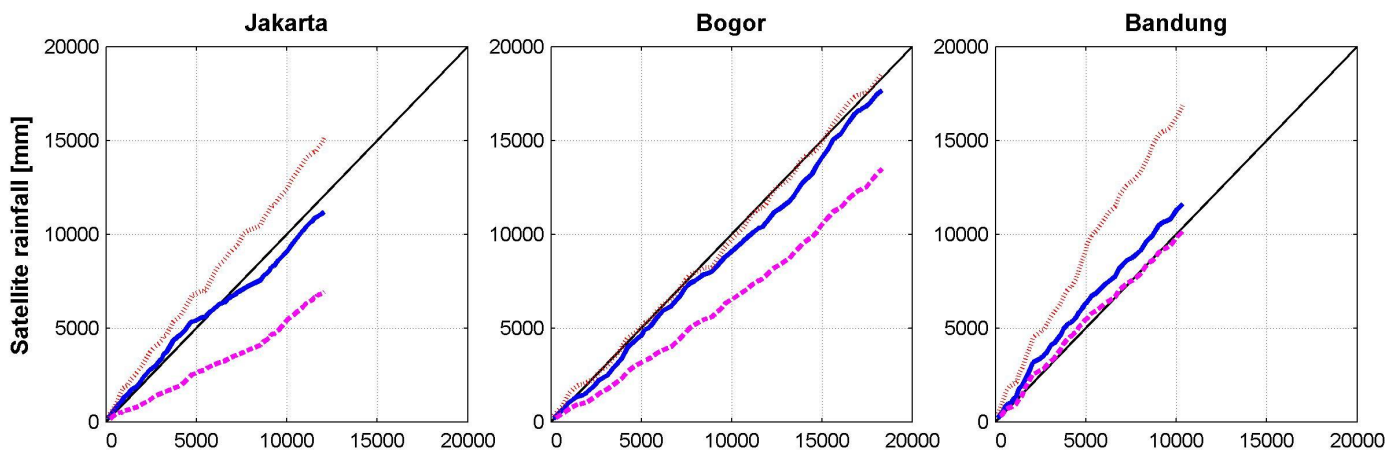

$-\mathrm{X}=\mathrm{Y} \longrightarrow$ TMPA 3B42RT -..-..-" CMORPH
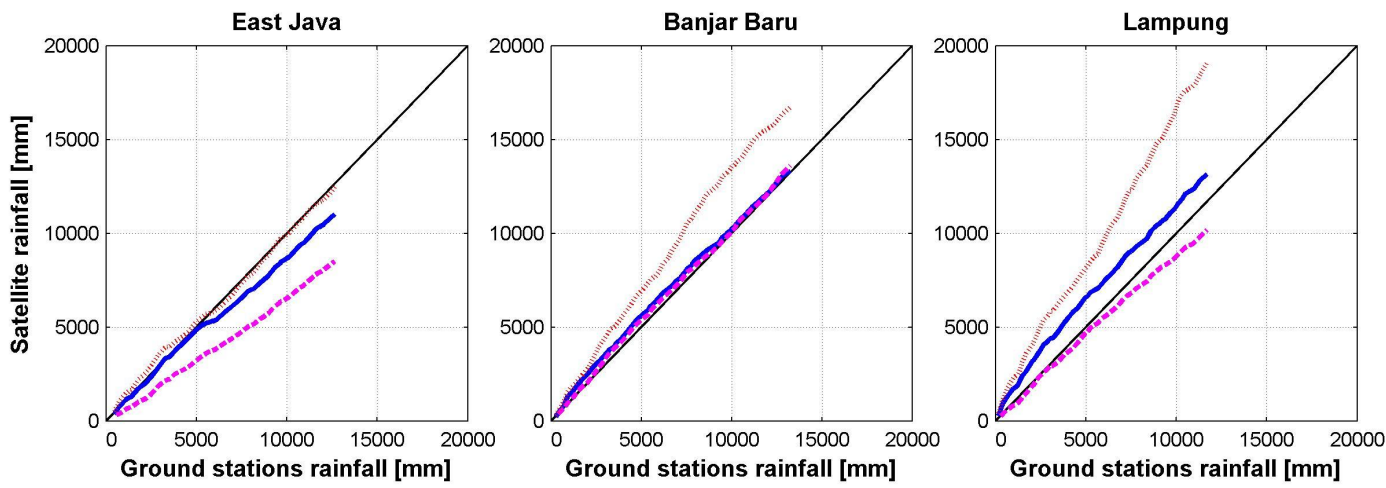

Fig. 4. Double mass curves showing the accumulated amount of rainfall of the observations against the satellite estimates (TMPA 3B42RT, CMORPH and PERSIANN) for each of the six validation areas for 2003-2008.

Table 3. Average dry season (June-October) precipitation ( $P$, in $\mathrm{mm})$ and relative bias (\%) over the period 2003-2008 for ground stations, and satellite products TMPA 3B42RT, CMORPH and PERSIANN.

\begin{tabular}{|c|c|c|c|c|c|c|c|}
\hline \multirow[t]{2}{*}{$\begin{array}{l}\text { Validation } \\
\text { region }\end{array}$} & \multirow{2}{*}{$\begin{array}{r}\text { Ground } \\
\text { stations } \\
P\end{array}$} & \multicolumn{2}{|c|}{ TMPA } & \multicolumn{2}{|c|}{ CMORPH } & \multicolumn{2}{|c|}{ PERSIANN } \\
\hline & & $P$ & rel. bias & $P$ & rel. bias & $P$ & rel. bias \\
\hline Jakarta & 319 & 276 & -13.5 & 261 & -18.1 & 349 & 9.5 \\
\hline Bogor & 715 & 539 & -24.6 & 400 & -44.1 & 375 & -47.5 \\
\hline Bandung & 286 & 204 & -28.7 & 169 & -41.1 & 207 & -27.5 \\
\hline East Java & 166 & 75 & -55.1 & 74 & -55.6 & 60 & -63.7 \\
\hline Banjar Baru & 462 & 467 & 1.0 & 502 & 8.7 & 423 & -8.5 \\
\hline Lampung & 367 & 255 & -30.3 & 237 & -35.4 & 377 & 3.0 \\
\hline
\end{tabular}

\subsection{Determining a bias correction equation for TMPA 3B42RT rainfall data}

Comparison with ground station measurements showed the TMPA 3B42RT product to be the most accurate satellite rainfall product (Tables 2 and 3). Moreover, comparison with other satellite products revealed large differences. The TMPA 3B42RT data were identified as the most suitable source of satellite rainfall information. However, there were differences with ground station data that may be reduced.
We therefore obtained a bias correction equation to achieve a closer fit between monthly TMPA 3B42RT and ground station averages. To accommodate for the finding that relative bias varied with total monthly rainfall, a power function was applied to derive bias corrected rainfall $\left(P^{*}\right)$ :

$P^{*}=a *\left(P / P_{0}\right)^{b}$

where the reference monthly rainfall $\left(P_{0}, 1 \mathrm{~mm}\right.$ per month) is introduced to maintain correct dimensions, and the parameters $a(\mathrm{~mm})$ and $b$ (dimensionless) were derived by 

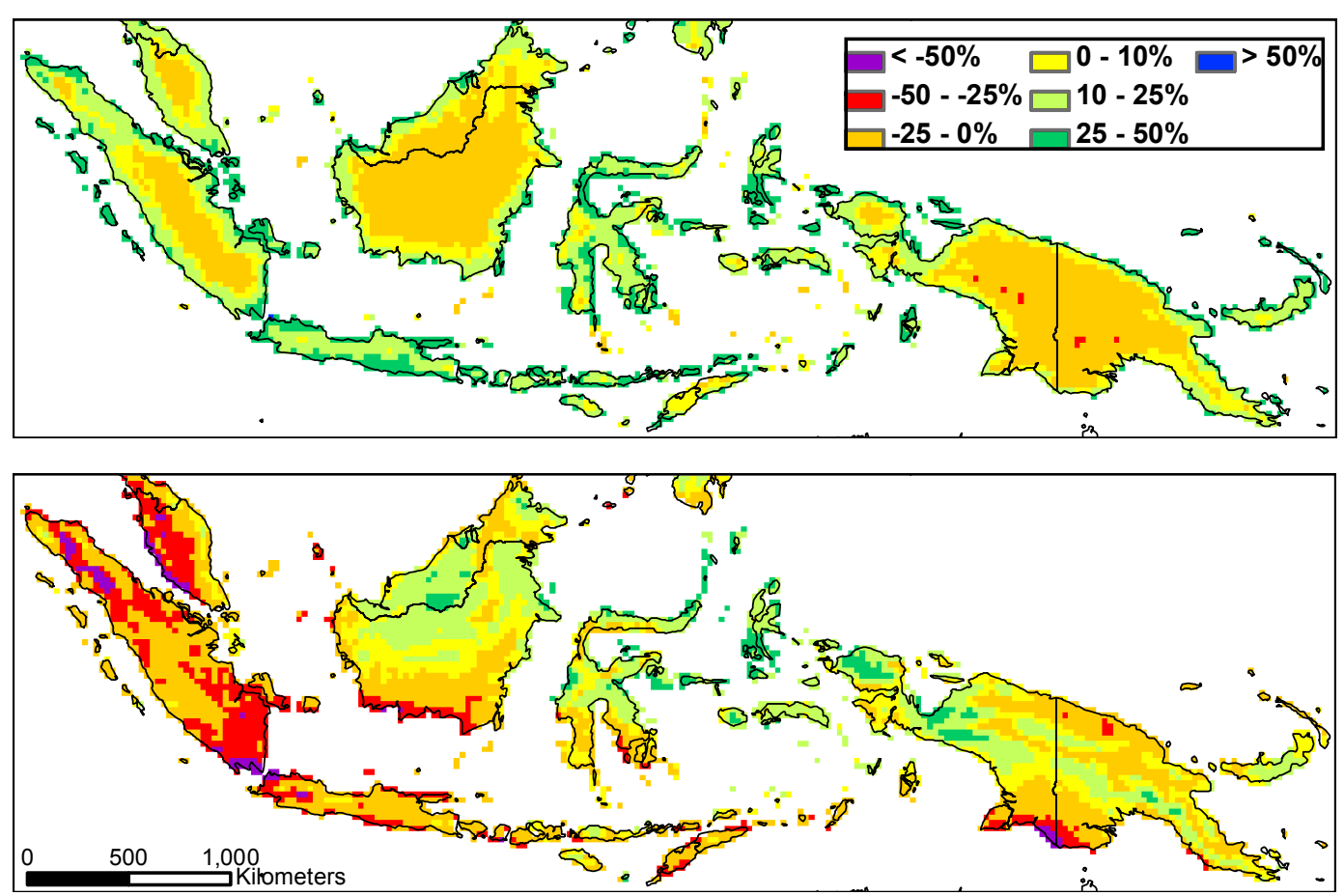

Fig. 5. Relative difference in annual average rainfall over the period 2003-2008 between TMPA 3B42RT and CMORPH (top panel) and TMPA 3B42RT and PERSIANN (lower panel).

minimizing both the annual and dry season sum of average monthly differences between bias corrected and ground station measurements for all 6 validation areas together. The generalized reduced gradient algorithm (Fylstra et al., 1998) was used to obtain an optimized value of 3.20 for $a$ and 0.79 for $b$. In Fig. 6 a scatter plot of average monthly rainfall for ground station data for all 6 validation areas and uncorrected and bias corrected TMPA 3B42RT is shown. This non-linear bias-correction mitigated the underestimation by TMPA of rainfall in dry months, without leading to an overestimation of rainfall during wet months (Fig. 6). The fraction of variance in log-transformed observed monthly rainfall for the 6 sites combined that was explained by the satellite rainfall estimates increased from 0.78 to 0.93 after bias correction. The distribution of average monthly rainfall over the year for ground station data and uncorrected and bias corrected TMPA 3B42RT data is shown in Fig. 7, and the monthly time series in Fig. 8. The average difference, relative bias and RMSE of the bias corrected TMPA 3B42RT rainfall are given in Tables 4 and 5 for each of the individual validation areas. Although relative bias only improved for 2 of the 6 validation areas on an annual basis, RMSE improved in all cases, by $6 \%$ for Banjar Baru to $24 \%$ for Lampung (Table 4 ). For the dry season, relative bias improved for 5 of the 6 validation areas, and RMSE improved for 4 of the 6 validation areas, by 12 to $26 \%$ (Table 5).

\section{Discussion}

\subsection{Comparison of different satellite rainfall estimates over Indonesia}

All comparisons showed the TMPA 3B42RT data to be more accurate overall than the two other products evaluated. In terms of daily (rather than monthly) rainfall, Ebert et al. (2007) found the CMORPH product appeared to be best overall, followed by PERSIANN in the wet season, and TMPA in the dry season. This difference may be related to the different environments considered and the lesser degree of calibration of the different products for Indonesia. Rainfall in Indonesia is dominated by convective events, and very few ground station data will have been available for calibration for any of the three products.

In almost all validation areas, the (uncorrected) satellite rainfall products underestimated rainfall in dry months and overestimated rainfall in wet months (shown for TMPA 3B42RT in Fig. 8). These tendencies are consistent with published studies. Ebert et al. (2007) compared several satellite precipitation products for northern Australia $\left(10-25^{\circ} \mathrm{S}\right)$ and found that performance was notably less good for dry season rainfall. This was attributed to the dominance of nonconvective rainfall during this season, brought in from midlatitudes by remnant frontal systems or orographic lifting of most ocean air. Underestimation of low rainfall events has also been found in other regions, particularly during 

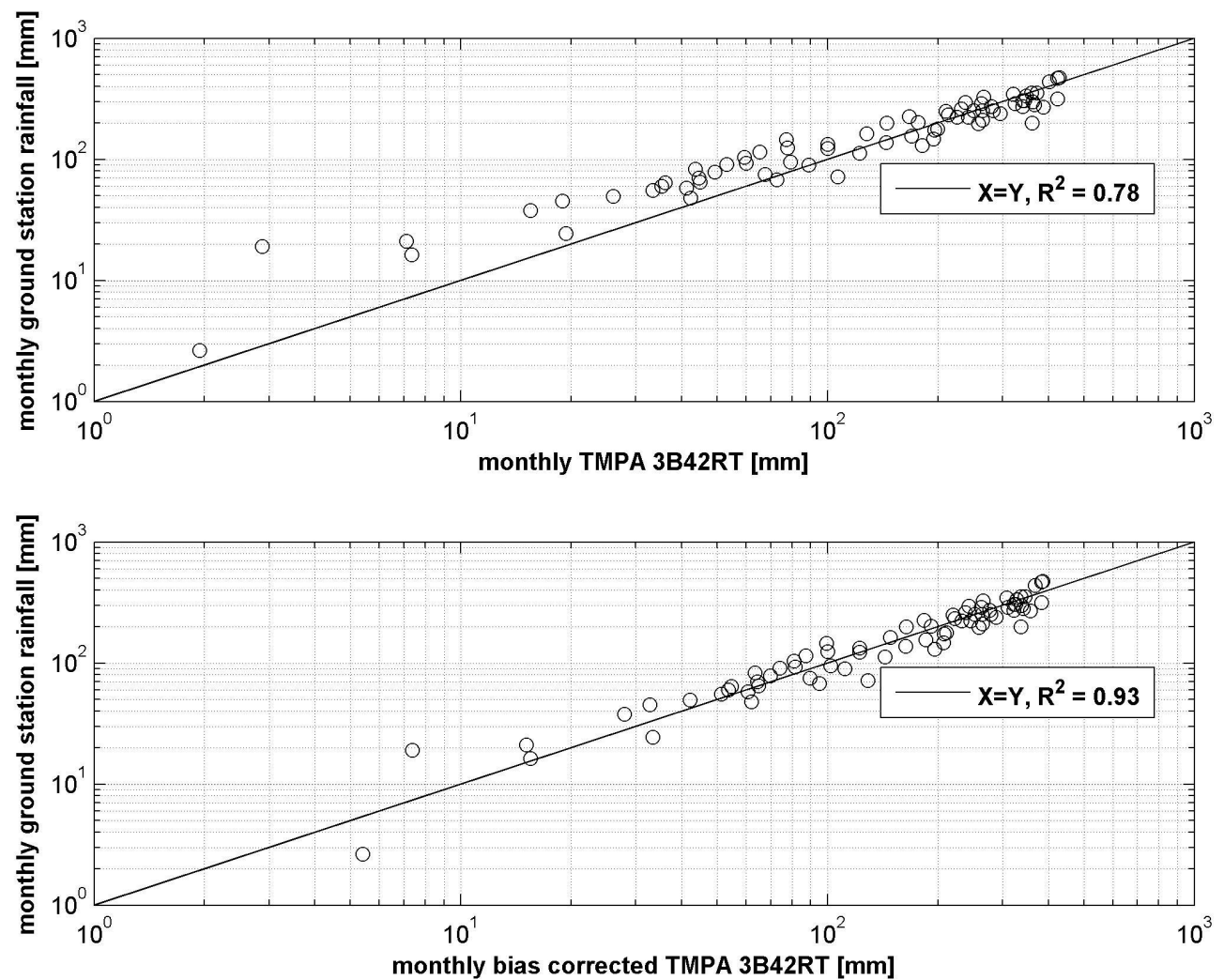

Fig. 6. Average monthly uncorrected TMPA 3B42RT (top panel) and bias corrected TMPA 3B42RT (lower panel) over 2003-2008 for all 6 validation areas together compared with ground station data (both on logarithmic axis).

Table 4. Annual ground station and TMPA 3B42RT precipitation ( $P$, in mm per year), average difference, relative bias (\%, to observations), RMSE (in mm per month) and correlation coefficients before and after bias correction of TMPA 3B42RT precipitation estimates over the period 2003-2008.

\begin{tabular}{|c|c|c|c|c|c|c|c|c|c|c|c|}
\hline \multirow[t]{2}{*}{$\begin{array}{l}\text { Validation } \\
\text { region }\end{array}$} & \multirow{2}{*}{$\begin{array}{r}\text { Ground } \\
\text { stations } \\
P\end{array}$} & \multicolumn{5}{|c|}{ TMPA } & \multicolumn{5}{|c|}{$\begin{array}{c}\text { TMPA } \\
\text { bias corr. }\end{array}$} \\
\hline & & $P$ & $\begin{array}{l}\text { Avg. } \\
\text { diff. }\end{array}$ & $\begin{array}{l}\text { rel. } \\
\text { bias }\end{array}$ & RMSE & $R^{2}$ & $P$ & $\begin{array}{l}\text { Avg. } \\
\text { diff. }\end{array}$ & rel. bias & RMSE & $R^{2}$ \\
\hline Jakarta & 2010 & 1865 & -145 & -7.2 & 83.8 & 0.84 & 1918 & -92 & -4.6 & 78.2 & 0.84 \\
\hline Bogor & 3056 & 2944 & -112 & -3.7 & 94.9 & 0.83 & 2845 & -211 & -6.9 & 79.8 & 0.84 \\
\hline Bandung & 1723 & 1936 & 213 & 12.3 & 85.8 & 0.84 & 1965 & 242 & 14.0 & 71.6 & 0.86 \\
\hline East Java & 2106 & 1835 & -271 & -12.8 & 56.0 & 0.95 & 1819 & -287 & -13.6 & 49.3 & 0.96 \\
\hline Banjar Baru & 2208 & 2217 & 9 & 0.4 & 59.6 & 0.84 & 2303 & 95 & 4.3 & 56.0 & 0.85 \\
\hline Lampung & 1946 & 2190 & 244 & 12.6 & 83.8 & 0.89 & 2200 & 254 & 13.1 & 63.6 & 0.90 \\
\hline Avg. total & 2175 & 2165 & -10 & 0.3 & 77.3 & 0.87 & 2175 & $\mathbf{0}$ & 1.0 & 66.4 & 0.88 \\
\hline
\end{tabular}

the cool season (Ebert et al., 2007; Villarini and Krajewski, 2007), (although Scheel et al. (2011) found overestimation for Cusco in Peru and La Paz in Bolivia). Rainfall detection in infrared wavelengths relies on sufficiently cooling of cloud tops, which does not necessarily occur in frontal systems or moist ocean air inflow. In the Indonesian context, high cirrus type clouds are important during the dry season (Franchito et al., 2009). They are also associated with low rainfall intensities and may cause similar detection problems. For the three products we examined here, Ebert et al. (2007) found that they overestimated high rainfall, the TMPA product more so than for the other two. Similar overestimates 

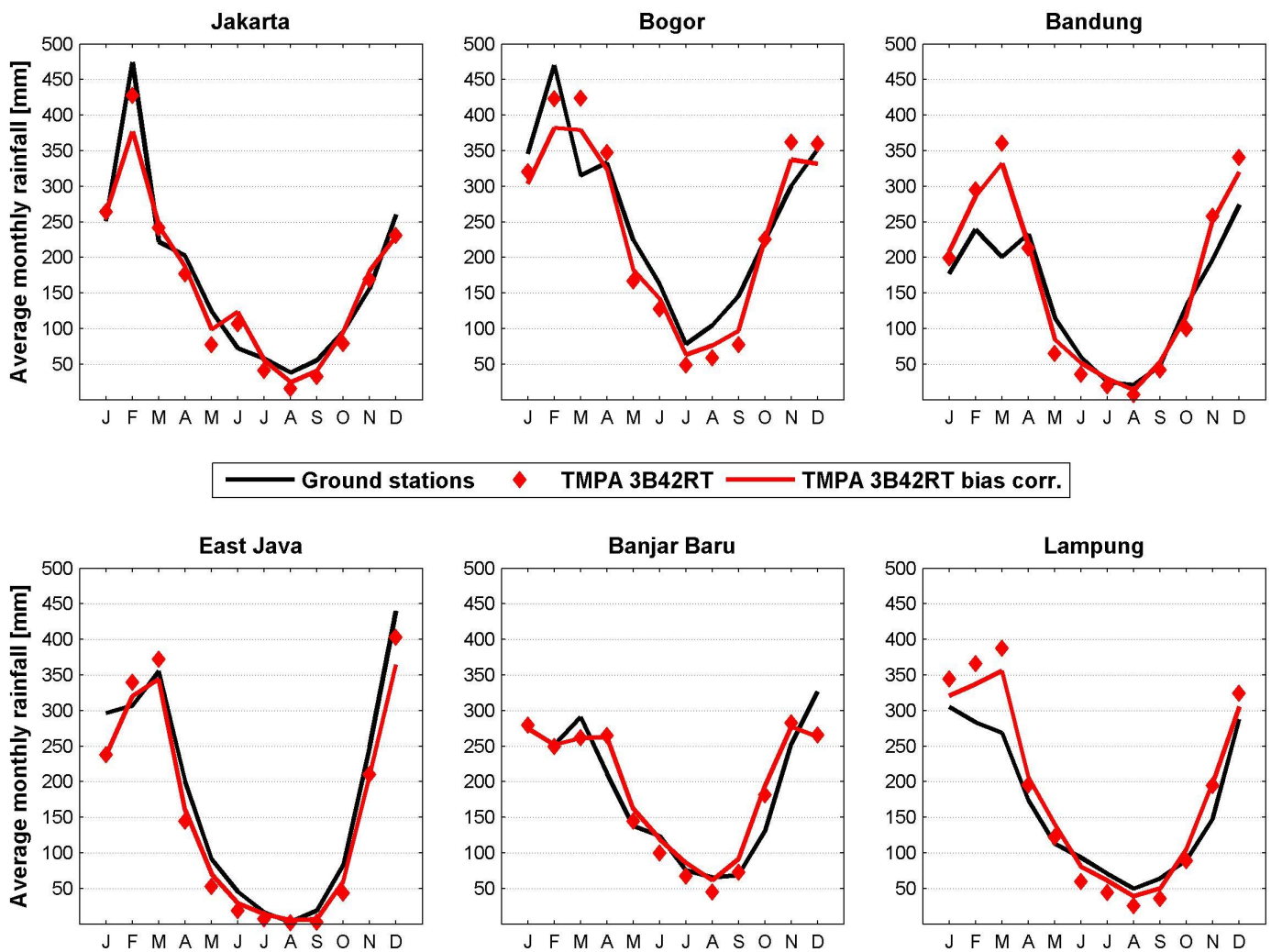

\section{TMPA 3B42RT — TMPA 3B42RT bias corr.}
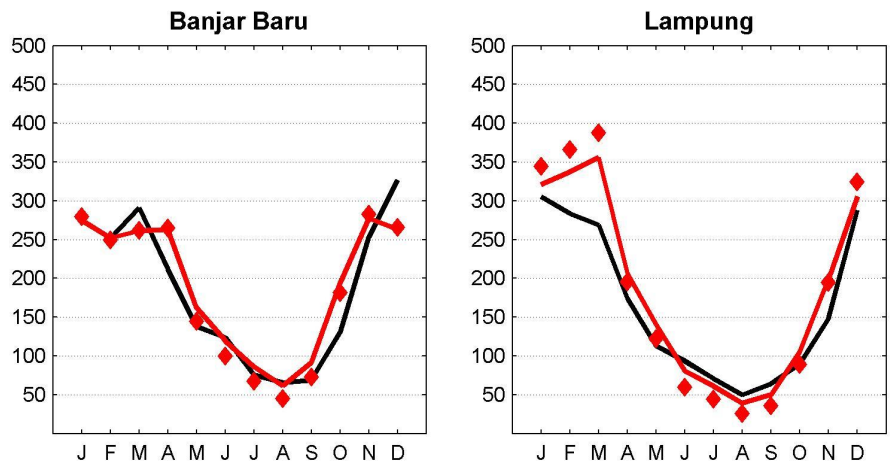

Fig. 7. Average monthly bias corrected TMPA 3B42RT data over 2003-2008, compared with ground station and uncorrected TMPA 3B42RT data.

Table 5. Dry season (June-October) ground station and TMPA 3B42RT precipitation ( $P$, in mm per season), average difference, relative bias (\%, to observations), RMSE (in mm per month) and correlation coefficients before and after bias correction of TMPA 3B42RT precipitation estimates over the period 2003-2008.

\begin{tabular}{|c|c|c|c|c|c|c|c|c|c|c|c|}
\hline \multirow[t]{2}{*}{$\begin{array}{l}\text { Validation } \\
\text { region }\end{array}$} & \multirow{2}{*}{$\begin{array}{r}\text { Ground } \\
\text { stations } \\
P\end{array}$} & \multicolumn{5}{|c|}{ TMPA } & \multicolumn{5}{|c|}{$\begin{array}{c}\text { TMPA } \\
\text { bias corr. }\end{array}$} \\
\hline & & $P$ & $\begin{array}{l}\text { Avg. } \\
\text { diff. }\end{array}$ & $\begin{array}{r}\text { rel. } \\
\text { bias }\end{array}$ & RMSE & $R^{2}$ & $P$ & $\begin{array}{l}\text { Avg. } \\
\text { diff. }\end{array}$ & rel. bias & RMSE & $R^{2}$ \\
\hline Jakarta & 319 & 276 & -43 & -13.5 & 50.5 & 0.62 & 340 & 21 & 6.6 & 51.2 & 0.65 \\
\hline Bogor & 715 & 539 & -176 & -24.6 & 72.9 & 0.78 & 604 & -111 & -15.5 & 64.1 & 0.79 \\
\hline Bandung & 286 & 204 & -82 & -28.7 & 33.9 & 0.87 & 265 & -21 & -7.3 & 29.7 & 0.87 \\
\hline East Java & 166 & 75 & -91 & -55.1 & 31.8 & 0.91 & 114 & -52 & -31.3 & 23.6 & 0.92 \\
\hline Banjar Baru & 462 & 467 & 5 & 1.0 & 36.0 & 0.85 & 551 & 89 & 19.3 & 40.2 & 0.85 \\
\hline Lampung & 367 & 255 & -121 & -30.3 & 39.9 & 0.71 & 336 & -31 & -8.4 & 32.2 & 0.77 \\
\hline Avg. total & 386 & 303 & -83 & -25.2 & 44.2 & 0.79 & 368 & -18 & -6.1 & 40.2 & 0.81 \\
\hline
\end{tabular}

have also been reported in other studies (e.g. Behrangi et al., 2011; Curtis et al., 2007; Katsanos et al., 2004; Su et al., 2008; but not Scheel et al., 2011). In the present study, dry season rainfall underestimates and wet season overestimates led, on average, to unbiased estimates of annual rainfall. It seems plausible that this reflects compensation in the three remote sensing methods, that is, calibration against ground-measured data may have led to an overestimation of rainfall from larger, detected events (mainly occurring during the wet season) in order to compensate for undetected or underestimated small events.

The spatial differences between the different satellite rainfall products are striking, in particular in coastal areas and at higher altitudes (Fig. 5). PERSIANN showed lower 

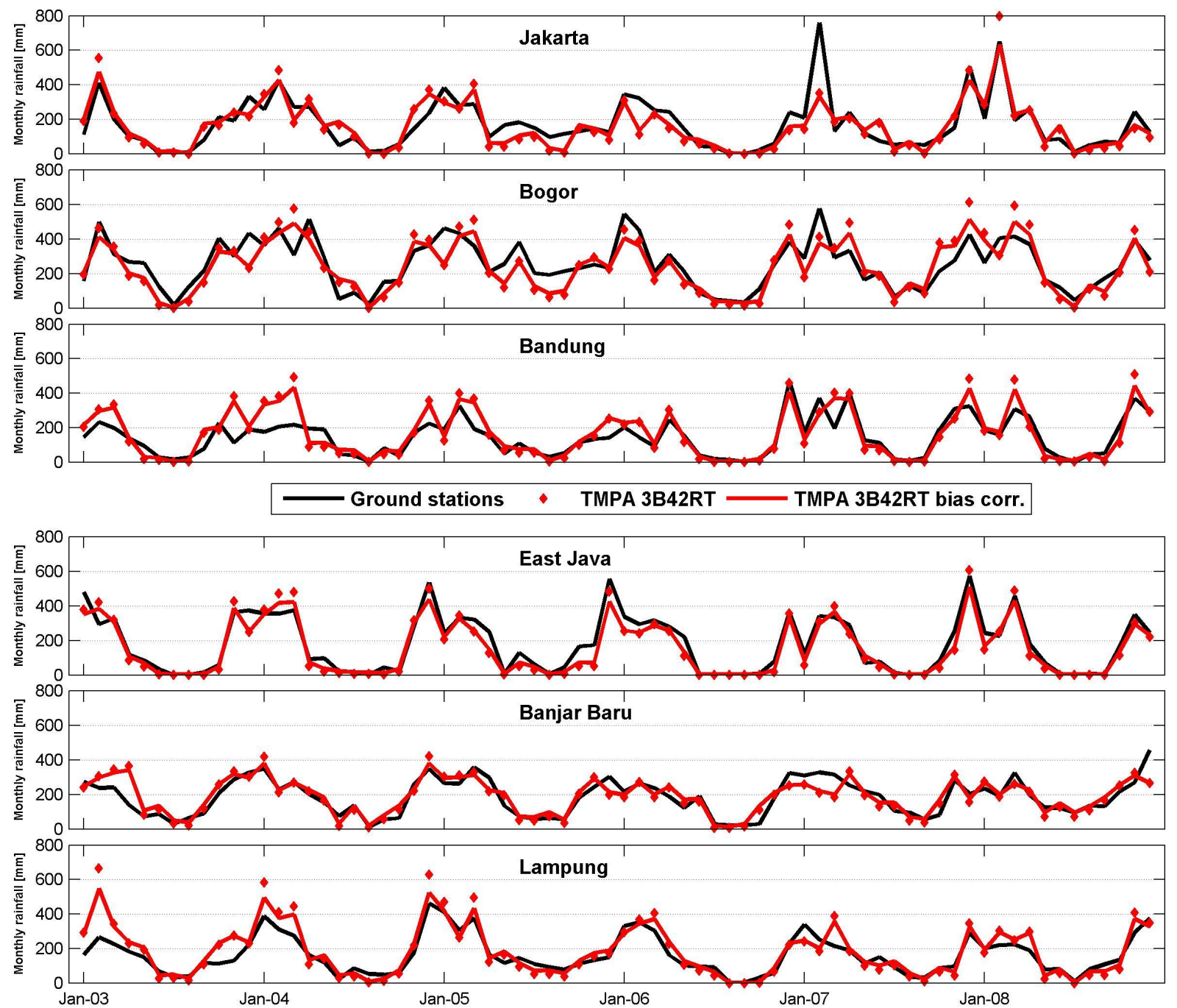

Fig. 8. Comparison of average monthly ground station rainfall with bias corrected and uncorrected TMPA 3B42RT for the individual validation areas.

estimates in high altitude areas than the other two products. On the basis of the physics of rainfall remote sensing, most authors predict that satellite rainfall products are more likely to underestimate than overestimate rainfall in high altitude areas (Hirpa et al., 2009), and therefore the PERSIANN estimates may be the less realistic. Artifacts in satellite rainfall estimates can arise in coastal areas because different retrieval methods are required over land and sea, respectively. In this case it would appear that the TMPA and PERSIANN products show more consistency, but we cannot assess which estimates are the more accurate.

\subsection{Suitability of bias corrected TMPA 3B42RT data for monthly rainfall monitoring}

Although patterns in uncorrected TMPA 3B42RT rainfall closely resemble patterns in ground station rainfall in Indonesia, they consistently underestimate rainfall in dry periods
(Table 3). When uncorrected TMPA 3B42RT data would be used for water resources management purposes, this underestimation of rainfall would introduce an overestimation of water deficits. After bias correction on a monthly basis, rainfall difference in ground station measurements and TMPA 3B42RT data over the dry season was reduced for 5 out of 6 areas, evident from an improved RMSE (Table 5). The bias correction reduced the station-average difference between ground station and TMPA 3B42RT rainfall over the June-October "dry season" period from 83 to $18 \mathrm{~mm}$, or only $3.6 \mathrm{~mm} \mathrm{month}^{-1}$ on an average monthly rainfall amount of $77 \mathrm{~mm}$ (Table 5). This is a distinct improvement, although greater deviations remain for individual areas: from $111 \mathrm{~mm}$ in Bogor to $-89 \mathrm{~mm}$ for Banjar Baru. However on a monthly basis the latter deviations are still within $25 \mathrm{~mm} \mathrm{month}^{-1}$. We consider this to be a useful accuracy for many water resources management applications. 


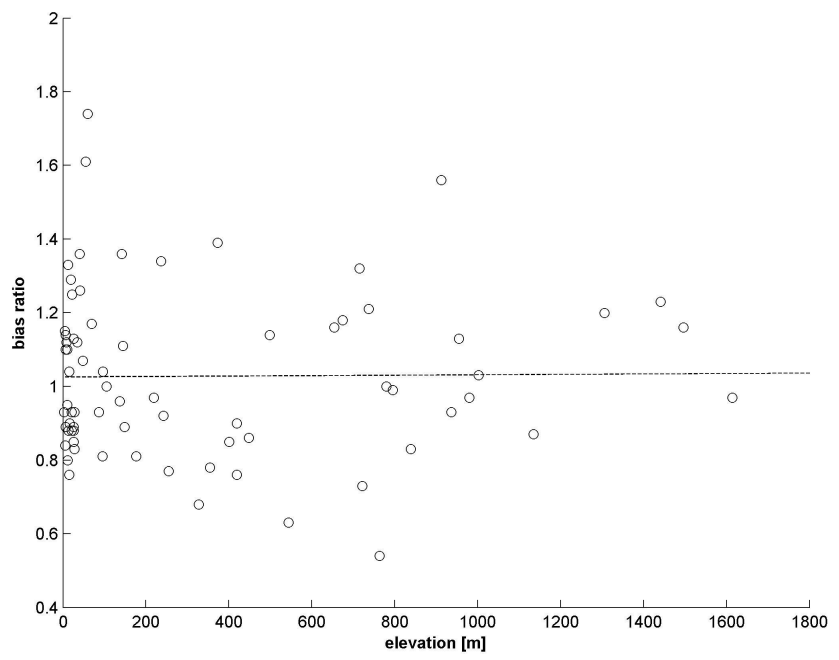

Fig. 9. Bias ratio vs. elevation for the individual ground stations in the six validation areas $\left(R^{2}=0.0001, n=73\right.$; of the 76 available stations (Table 1), 3 did not have any full year of validated observations).

On an annual basis, the bias correction removed the difference between ground station and TMPA 3B42RT rainfall averaged over all areas. However, significant differences remain for individual areas, ranging from $287 \mathrm{~mm} \mathrm{yr}^{-1}$ in East Java to $-254 \mathrm{~mm} \mathrm{yr}^{-1}$ in Lampung (Table 4). This is up to $15 \%$ of the $\sim 2000 \mathrm{~mm} \mathrm{yr}^{-1}$ rainfall that these locations receive. A smaller deviation would be preferable, but it should be considered that for much of Indonesia, the low spatial coverage and variable quality of ground station records will not allow a better measurement of average rainfall over large areas. Moreover, there was some evidence that TMPA 3B42RT rainfall estimates in the wet season improved since 2005.

It is noted that the ground stations used in this validation do not cover all climatic regions of Indonesia (Aldrian and Susanto, 2003) and there is a systematic under-sampling in higher altitude and forested areas. The latter is due to the simple fact that rainfall in Indonesia (and indeed many countries) is mainly measured in densely populated and deforested lowlands and valleys. For six river basins of Ethiopia, Romilly and Gebremichael (2011) found that the accuracy of TMPA satellite rainfall estimates depended on elevation. Using a similar analysis approach we found no apparent relationship between the bias ratio (TMPA 3B42RT precipitation estimate divided by average annual gauge precipitation, calculated for each individual measurement station) and elevation (Fig. 9, $R^{2}=0.0001$ ). An independent test using measurements from the Southeast Asian Climate Assessment (SACA) dataset (Klein Tank et al., 2011) in Northern Territory, Australia, shows that our bias correction also improved monthly (and annual) precipitation estimates (Fig. 10) in that region. This provides more confidence that the derived bias correction may help remove bias in TMPA estimates for other tropical regions.

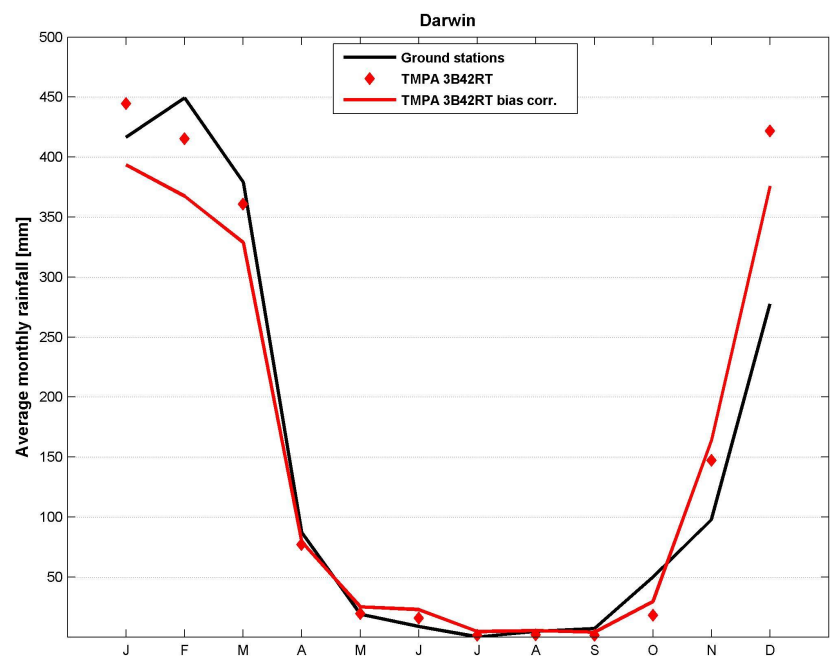

Fig. 10. Average monthly corrected TMPA 3B42RT data over 2003-2008, compared with ground station and uncorrected TMPA 3B42RT data for a TMPA grid cell in the Northern Territory (Darwin), Australia. Average annual precipitation 4 ground stations (Darwin airport, Karama, Leanyer and Shoal Bay) $=1797 \mathrm{~mm}$, average annual uncorrected TMPA 3B42RT $=1926 \mathrm{~mm}$ and average annual bias corrected TMPA 3B42RT $=1801 \mathrm{~mm} . \quad R^{2}$ uncorrected TMPA 3B42RT $=0.90 ; R^{2}$ bias corrected TMPA 3B42RT $=0.91$; RMSE uncorrected TMPA 3B42RT $=94.8 \mathrm{~mm}$ per month; RMSE bias corrected TMPA 3B42RT $=85.6 \mathrm{~mm}$ per month.

Maps of average annual and dry season rainfall, generated using bias corrected TMPA 3B42RT data, are presented in Fig. 11. This clearly shows the large spatial and temporal variation in rainfall that exists in Indonesia, with annual rainfall rates varying from above 3000 to below $1500 \mathrm{~mm} \mathrm{yr}^{-1}$, and with even greater relative differences in the dry season. The latter is even more apparent when comparing a relative wet dry season month (October 2007) with the same month in the 2006 El Niño year (Fig. 11c, d).

Clearly such major variations necessitate the use of accurate and real time rainfall information in water resources management and crop planning. The availability of up-todate maps of rainfall patterns may also allow better planning of reservoir dimensions and the location of agricultural activities that are very sensitive to drought. The limited spatial coverage of ground stations and climate change mean that rainfall distribution maps based on historical ground station rainfall data are not necessarily always accurate. It would be best to enhance such maps using up-to-date and accurate satellite data.

In addition to the bias correction of the TMPA 3B42RT data, there are other avenues to produce better estimates of rainfall. Inter-comparison studies such as those by Ebert et al. (2007) clearly show the complementary performance of precipitation estimates derived from weather prediction models and precipitation remote sensing, with the two performing best for non-convective and convective rainfall conditions, 

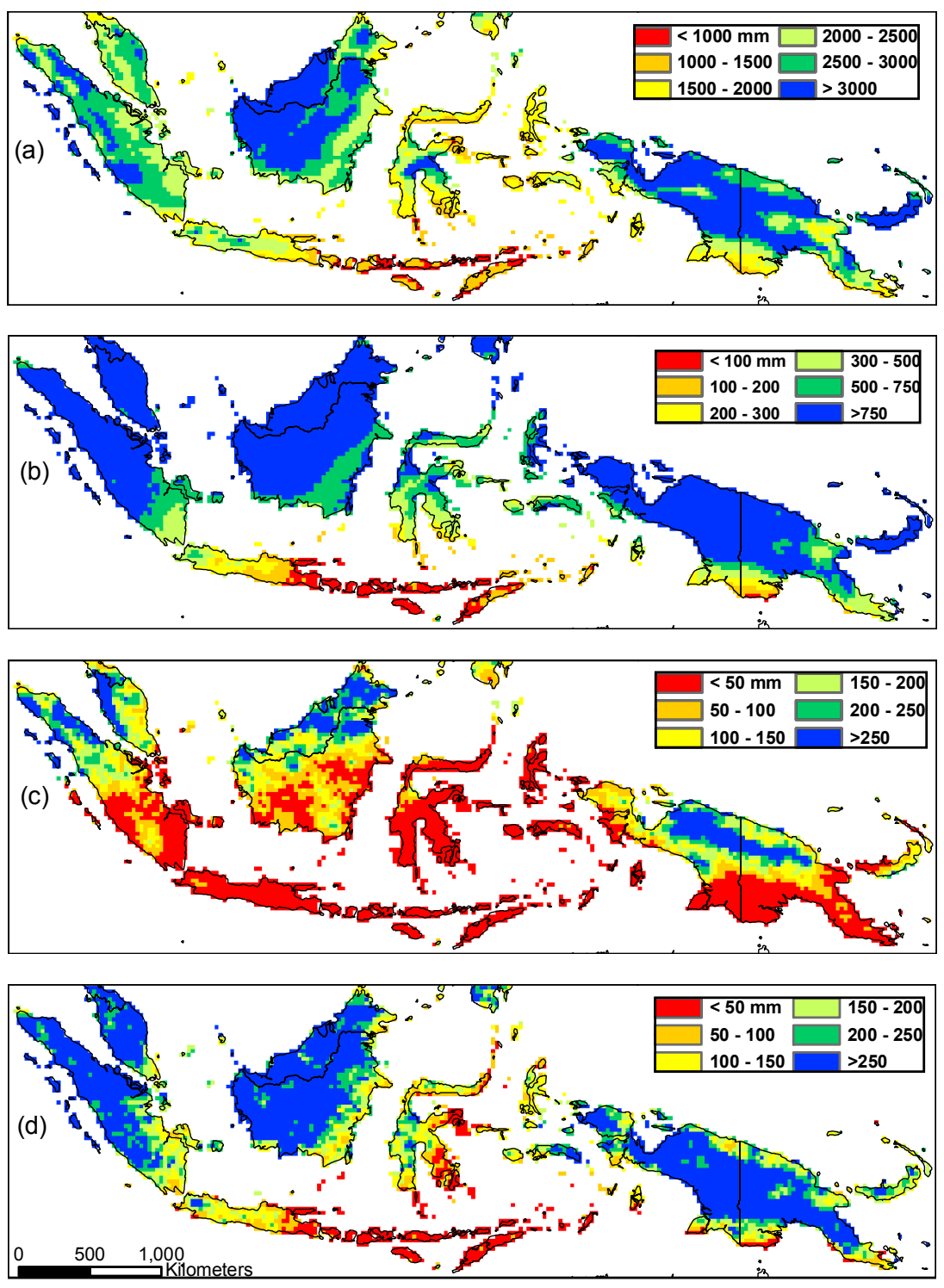

Fig. 11. (a) Average annual and (b) dry season (June-October) rainfall as determined from monthly bias corrected TMPA 3B42RT over 2003-2008 as well as (c) October 2006 and (d) October 2007 bias corrected TMPA 3B42RT rainfall.

respectively. In addition, early research suggests it may be possible to constrain satellite precipitation estimates using remotely sensed soil moisture estimates to filter out any additional errors (Crow and Ryu, 2009). Finally, further improvements in satellite rainfall estimates may be expected with the new missions, in particular the Global Precipitation Measurement mission planned for launch in 2014 (Smith et al., 2007).

\section{Conclusions}

TMPA 3B42RT satellite rainfall data appeared to have greater accuracy than two other products (PERSIANN, CMORPH) and bias correction on a monthly basis further improved accuracy. We consider the resulting estimates to be sufficiently accurate for use in near real-time monitoring of rainfall and the development of drought conditions in Indonesia, in support of water resources management, agriculture and fire prevention. A Drought Early Warning System (DEWS) for Indonesia using the bias corrected TMPA rainfall estimates is currently being developed. Further research is recommended to determine whether this or a similar bias correction may also produce better rainfall estimates in other regions prone to periodic water shortages where high spatial variation in rainfall and lack of telemetered on-ground networks challenges drought early monitoring using ground stations alone. 
Acknowledgements. The work reported here was supported by Deltares internal R\&D funding and the SDWA Peatland Programme. The Delft-FEWS system was used for processing satellite data. Ground station rainfall data were provided by Perum Jasa Tirta I and BMKG, the latter which will collaborate on DEWS development through a Joint Cooperation programme between PusAir, BMKG, Deltares and KNMI. The manuscript benefited from the insightful comments of two anonymous referees.

Edited by: S. Thompson

\section{References}

Aldrian, E. and Djamil, Y. S.: Spatio-temporal climatic change of rainfall in East Java Indonesia, Int. J. Climatol., 28, 435-448, 2008.

Aldrian, E. and Susanto, R. D.: Identification of three dominant rainfall regions within Indonesia and their relationship to sea surface temperature, Int. J. Climatol., 23, 1435-1452, 2003.

Behrangi, A., Khakbaz, B., Jaw, T. C., AghaKouchak, A., Hsu, K., and Sorooshian, S.: Hydrologic evaluation of satellite precipitation products over a mid-size basin, J. Hydrol., 397, 225-237, 2011.

Brünig, E. F.: On the seasonality of droughts in the lowlands of Sarawak (Borneo), Erdkunde, 23, 127-133, 1969.

Crow, W. T. and Ryu, D.: A new data assimilation approach for improving runoff prediction using remotely-sensed soil moisture retrievals, Hydrol. Earth Syst. Sci., 13, 1-16, doi:10.5194/hess13-1-2009, 2009.

Curtis, S., Crawford, T. W., and Lecce, S. A.: A comparison of TRMM to other basin-scale estimates of rainfall during the 1999 Hurricane Floyd flood. Nat. Hazards, 43, 187-198, 2007.

Ebert, E. E., Janowiak, J. E., and Kidd, C.: Comparison of nearreal-time precipitation estimates from satellite observations and numerical models, B. Am. Meteorol. Soc., 88, 47-64, 2007.

ESA: GlobCover Land Cover v2.2, European Space Agency GlobCover Project, led by MEDIAS-France, available at: http:// ionia1.esrin.esa.int/index.asp, last access: 25 August 2009, 2008.

Field, R. D., Wang, Y., Roswintiarti, O., and Guswanto: A droughtbased predictor of recent haze events in western Indonesia, Atmos. Environ., 38, 1869-1878, 2004.

Franchito, S. H., Rao, V. B., Vasques, A. C., Santo, C. M. E., and Conforte, J. C.: Validation of TRMM precipitation radar monthly rainfall estimates over Brazil, J. Geophys. Res., 114, D02105, doi:10.1029/2007JD009580, 2009.

Fylstra, D., Lasdon, L., Watson, J., and Waren, A.: Design and use of the Microsoft Excel solver, Interfaces, 28, 29-55, 1998.

Hirpa, F. A., Gebremichael, M., and Hopson, T.: Evaluation of high-resolution satellite precipitation products over very complex terrain in Ethiopia, J. Appl. Meteorol. Climatol., 49, 1044$1051,2010$.

Hsu, K., Gao, X., Sorooshian, S., and Gupta, H. V.: Precipitation estimation from remotely sensed information using artificial neural networks, J. Appl. Meteorol., 36, 1176-1190, 1997.

Huffman, G. J. and Bolvin, D. T.: Real-Time TRMM Multi-Satellite Precipitation Analysis data set documentation, laboratory for atmospheres, NASA Goddard space flight center and science systems and applications, Inc., 2010, available at: ftp://meso-a.gsfc.
nasa.gov/pub/trmmdocs/rt/3B4XRT_doc.pdf, last access: February 2011, 2010.

Huffman, G. J., Adler, R. F., Bolvin, D. T., Gu, G., Nelkin, E. J., Bowman, K. P., Hong, Y., Stocker, E. F., and Wolff, D. B.: The TRMM Multisatellite Precipitation Analysis (TMPA): quasi-global, multiyear, combined-sensor precipitation estimates at fine scales, J. Hydrometeorol., 8, 38-55, 2007.

Jarvis, A., Reuter, H. I., Nelson, A., and Guevara, E.: Holefilled seamless SRTM data V4, International Centre for Tropical Agriculture (CIAT), available at: http://srtm.csi.cgiar.org, last access: 3 July 2008, 2008.

Joyce, R. J., Janowiak, J. E., Arkin, P. A., and Xie, P.: CMORPH: A method that produces global precipitation estimates from passive microwave and infrared data at high spatial and temporal resolution, J. Hydrometeorol., 5, 487-503, 2004.

Katsanos, D., Lagouvardos, K., Kotroni, V., and Huffmann, G. J.: Statistical evaluation of MPA-RT high-resolution precipitation estimates from satellite platforms over the central and eastern Mediterranean, Geophys. Res. Lett., 31, L06116, doi:10.1029/2003GL019142, 2004.

Klein Tank, A. M. G. and Coauthors:. Daily dataset for climate extremes analyses in Southeast Asia, in preparation, Data and metadata available at: http://saca-bmkg.knmi.nl, last access: 22 March 2011, 2011.

Kirono, D. G. C. and Tapper, N. J.: ENSO rainfall variability and impacts on crop production in Indonesia, Phys. Geogr., 20, 508519, 1999.

Naylor, R. L., Falcon, W. P., Rochberg, D., and Wada, N.: Using El Nino/Southern Oscillation climate data to predict rice production in Indonesia, Climatic Change, 50, 255-265, 2001.

Oldeman, L. R., Las, I., and Darwis, S. N.: An agroclimatic map of Sumatra, Contributions, Central Research Institute for Agriculture, Bogor, No. 52, 35 pp., 1979.

Oldeman, L. R., Las, I., and Muladi: The agroclimatic maps of Kalimantan, Maluku, Irian Jaya and Bali, West and East Nusa Tenggara, Contributions, Central Research Institute for Agriculture, Bogor, No. 60, 32 pp., 1980.

Romilly, T. G. and Gebremichael, M.: Evaluation of satellite rainfall estimates over Ethiopian river basins, Hydrol. Earth Syst. Sci., 15, 1505-1514, doi:10.5194/hess-15-1505-2011, 2011.

Sapiano, M. R. P. and Arkin, P. A.: An intercomparison and validation of high-resolution satellite precipitation estimates with 3-hourly gauge data, J. Hydrometeorol., 10, 149-166, doi:10.1175/2008JHM1052.1, 2009.

Scheel, M. L. M., Rohrer, M., Huggel, Ch., Santos Villar, D., Silvestre, E., and Huffman, G. J.: Evaluation of TRMM Multi-satellite Precipitation Analysis (TMPA) performance in the Central Andes region and its dependency on spatial and temporal resolution, Hydrol. Earth Syst. Sci., 15, 2649-2663, doi:10.5194/hess-15-2649-2011, 2011.

Sheffield, J., Wood, E. F., Lettenmaier, D. P., and Lipponen, A.: Experimental Drought Monitoring for Africa, GEWEX News, 8, 2008.

Sorooshian, S., Hsu, K., Gao, X., Gupta, H. V., Imam, B., and Braithwaite, D.: Evaluation of PERSIANN system satellitebased estimates of tropical rainfall, B. Am. Meteorol. Soc., 81, 2035-2046, 2000.

Smith, E., Asrar, G., Furuhama, Y., et al.: International Global Precipitation Measurement (GPM) Program and Mission: An 
Overview, in: Measuring Precipitation From Space, edited by: Levizzani, V., Bauer, P., and Turk, F. J., Springer Netherlands, 611-653, 2007.

Su, F., Hong, Y., and Lettenmaier, D.: Evaluation of TRMM MultiSatellite Precipitation Analysis (TMPA) and its utility in hydrologic prediction in La Plata Basin, J. Hydrometeorol., 9, 622640, 2008.

van Dijk, A. I. J. M. and Renzullo, L. J.: Water resource monitoring systems and the role of satellite observations, Hydrol. Earth Syst. Sci., 15, 39-55, doi:10.5194/hess-15-39-2011, 2011.
Villarini, G. and Krajewski, W. F.: Evaluation of the research version TMPA three-hourly $0.25^{\circ} \times 0.25^{\circ}$ rainfall estimates over Oklahoma, Geophys. Res. Lett., 34, L05402, doi:10.1029/2006GL029147, 2007.

Wyrtki, K.: The rainfall over the Indonesian waters, Verhandelingen, Kementrian Perhubungan Lembaga Meteorologi dan Geofisika, Jakarta, No. 49, 24 pp., 1956. 